\title{
Validation of GOME-2/Metop total column water vapour with ground-based and in situ measurements
}

\author{
Niilo Kalakoski ${ }^{1}$, Jukka Kujanpää ${ }^{1}$, Viktoria Sofieva ${ }^{1}$, Johanna Tamminen ${ }^{1}$, Margherita Grossi ${ }^{2}$, and Pieter Valks ${ }^{2}$ \\ ${ }^{1}$ Finnish Meteorological Institute, Helsinki, Finland \\ ${ }^{2}$ Institut für Methodik der Fernerkundung (IMF), Deutsches Zentrum für Luft- und Raumfahrt (DLR), \\ Oberpfaffenhofen, Germany
}

Correspondence to: Niilo Kalakoski (niilo.kalakoski@fmi.fi)

Received: 5 September 2014 - Published in Atmos. Meas. Tech. Discuss.: 12 December 2014

Revised: 21 August 2015 - Accepted: 27 August 2015 - Published: 7 April 2016

\begin{abstract}
The total column water vapour product from the Global Ozone Monitoring Experiment-2 on board Metop$\mathrm{A}$ and Metop-B satellites (GOME-2/Metop-A and GOME2/Metop-B) produced by the Satellite Application Facility on Ozone and Atmospheric Chemistry Monitoring (O3M SAF) is compared with co-located radiosonde observations and global positioning system (GPS) retrievals. The validation is performed using recently reprocessed data by the GOME Data Processor (GDP) version 4.7.

The time periods for the validation are January 2007July 2013 (GOME-2A) and December 2012-July 2013 (GOME-2B). The radiosonde data are from the Integrated Global Radiosonde Archive (IGRA) maintained by the National Climatic Data Center (NCDC). The ground-based GPS observations from the COSMIC/SuomiNet network are used as the second independent data source.

We find a good general agreement between the GOME2 and the radiosonde/GPS data. The median relative difference of GOME-2 to the radiosonde observations is $-2.7 \%$ for GOME-2A and $-0.3 \%$ for GOME-2B. Against the GPS, the median relative differences are $4.9 \%$ and $3.2 \%$ for GOME-2A and B, respectively. For water vapour total columns below $10 \mathrm{~kg} \mathrm{~m}^{-2}$, large wet biases are observed, especially against the GPS retrievals. Conversely, at values above $50 \mathrm{~kg} \mathrm{~m}^{-2}$, GOME-2 generally underestimates both ground-based observations.
\end{abstract}

\section{Introduction}

Water vapour is the most important greenhouse gas accounting for about $60 \%$ of the greenhouse effect for clear skies (e.g. Kiehl and Trenberth, 1997). Knowledge of the spatiotemporal distribution and variability of water vapour is therefore very important for the assessment of climate change. Since ground-based observations do not provide a uniform global coverage (in particular, they are scarce over the oceans and in the polar areas), satellite observations are necessary to fill these gaps. Historically, water vapour has been measured from space using several different instruments: long time series over the oceans are available from microwave radiometers such as the Special Sensor Microwave/Imager (SSM/I) (e.g. Schlüssel et al., 1990) and its successor the Special Sensor Microwave Imager/Sounder (SSMIS). In the near-infrared band, observations are available from radiometers such as the Medium Resolution Imaging Spectrometer (MERIS) (e.g. Bennartz et al., 2001) and the Moderate Resolution Imaging Spectroradiometer (MODIS) (e.g. King et al., 1992; Gao et al., 2003). Long-term water vapour observations in the infrared band are available from instruments such as the TIROS Operational Vertical Sounder (TOVS), Advanced TOVS (ATOVS) and the Atmospheric Infrared Sounder (AIRS) (e.g. Chaboureau et al., 1998; Li et al., 2000; Susskind et al., 2003). Global positioning system (GPS) radio occultation data from the Constellation Observing System for Meteorology, Ionosphere, and Climate (COSMIC) mission have also been used to derive atmospheric water vapour (e.g. Anthes et al., 2008). 
Water vapour can be also measured using observations at UV and visible wavelengths. UV/VIS spectrometers like the Global Ozone Monitoring Experiment instrument on board the European Remote Sensing Satellite-2 (GOME/ERS-2) (Noël et al., 1999, 2002) and the Scanning Imaging Absorption spectrometer for Atmospheric Chartography (SCIAMACHY) on board the Envisat satellite (Noël et al., 2004) have provided observations from mid-1990s onwards. Operating at visible wavelengths, these instruments can observe the atmospheric water vapour column over all surfaces and have the advantage of having a high sensitivity to water vapour layers close to the surface. This makes UV/VIS observations useful in studies of tropospheric water vapour trends and variability.

Satellite observations are subject to their own limitations, which depend on the used measurement technique: UV/VIS sensors operate in daylight conditions and are usually limited by the presence of clouds. On the other hand, microwave measurements are typically limited to ocean areas, while infrared observations, in comparison to UV/VIS, are less sensitive to surface emissions from the lower atmospheric layers.

The Global Ozone Monitoring Experiment-2 (GOME2) is a nadir-viewing scanning spectrometer on board EUMETSAT's Metop-A (launched October 2006) and Metop-B (launched September 2012) satellites. Hereafter, we will refer to these as GOME-2A and GOME-2B, respectively. A third GOME-2 instrument is due to be launched on board the Metop-C satellite in 2018. The Metop series forms the space segment of the EUMETSAT Polar System (EPS), which is expected to operate at least until 2020. GOME-2 is dedicated to the observation of atmospheric trace gases, with a focus on the total ozone column and vertical ozone profiles. Other retrieved parameters include the total columns of nitrogen dioxide, sulfur dioxide, water vapour, bromine oxide, as well as other trace gases and aerosols. Both satellites are on sun-synchronous orbits with Equator crossing at 09:30 local time. Processing, dissemination, and archiving of the GOME-2 data products is handled by the EUMETSAT Satellite Application Facility on Ozone and Atmospheric Chemistry Monitoring (O3M SAF). The O3M SAF water vapour data are available from January 2007 onwards.

The O3M SAF GOME-2A water vapour has previously been compared with data from SCIAMACHY, which used a similar retrieval scheme. The GOME-2A and SCIAMACHY data were found to be in a good agreement, with a correlation coefficient of 0.99 and a mean bias of $0.5 \mathrm{~kg} \mathrm{~m}^{-2}$. Recently, Grossi et al. (2015) provided a detailed description of the improved GOME-2A and B algorithm and compared the results to the SSMIS measurements, a combined SSM/I + MERIS data set, and ECMWF model data. A good general agreement was reported with all three data sets, with a mean bias of $\pm 0.35 \mathrm{~kg} \mathrm{~m}^{-2}$ against all independent data sets analysed, although some seasonal and regional biases were identified. (Van Malderen et al., 2014) included GOME, SCIAMACHY and GOME-2 observations in the intercom- parison with ground-based, in situ and satellite observations. Wet bias was observed against GPS for GOME/GOME2/SCIAMACHY in cloud-free observations, with dry bias in cloudy scenes. (Antón et al., 2015) validated GOME-2A against radiosonde data from GRUAN network. They reported reasonably good correlation when all available reference data were used. However, observed differences showed dependency on cloud properties and viewing geometry.

The water vapour products from the GOME/ERS-2 and SCIAMACHY instruments, using similar measurement principles and retrieval algorithms as those used for GOME-2, have been extensively compared against the SSM/I observations. They were found to generally slightly underestimate the water vapour column in comparison to the SSM/I observations. The underestimation is more significant in cloudy conditions, especially in winter. The standard deviation (SD) of the differences is generally $3-5 \mathrm{~kg} \mathrm{~m}^{-2}$. However, in clearsky conditions, a good agreement is found (Noël et al., 1999, 2005; Wagner et al., 2003, 2005, 2006; Mieruch et al., 2010). Du Piesanie et al. (2013) validated the SCIAMACHY water vapour retrievals against radiosonde data and discussed the effect of clouds in water vapour retrievals.

Here, we report the geophysical validation of the GOME-2 water vapour total column against both radiosonde observations and ground-based GPS measurements. The text is organized as follows. In Sect. 2, we give a brief description of the GOME-2 instrument and the water vapour retrieval. Section 3 describes the data used in the validation and Sect. 4 the data selection and co-location criteria. The validation results are presented and discussed in Sect. 5.

\section{GOME-2 instrument and water vapour retrieval}

The GOME-2 sensors measure solar light scattered from the Earth's atmosphere and reflected from the surface at ultraviolet and visible wavelengths $(240-790 \mathrm{~nm})$ with a spectral resolution of $0.2-0.4 \mathrm{~nm}$. GOME-2 has a spatial resolution of $40 \mathrm{~km} \times 80 \mathrm{~km}$ with a swath width of $1920 \mathrm{~km}$, which provides daily global coverage at mid-latitudes. Each $6 \mathrm{~s}$ scan cycle consists of a $4.5 \mathrm{~s}$ forward scan ( 24 pixels with $40 \mathrm{~km} \times 80 \mathrm{~km}$ resolution) and a $1.5 \mathrm{~s}$ back scan ( 8 pixels with $40 \mathrm{~km} \times 240 \mathrm{~km}$ resolution). The data from both forward- and back-scan pixels are processed and written into data files (at the time of writing, the data from the back-scans are not recommended for use). At low solar elevation angles, longer integration times are used, resulting in an increased pixel size. Additionally, for 1 day (the 15th day) in every 29-day observation cycle, GOME-2A measures at narrow swath $(320 \mathrm{~km})$ mode. Since 15 July 2013, GOME-2A has been operating in a tandem mode with GOME-2B, with GOME-2A measuring with $960 \mathrm{~km}$ swath width and $40 \mathrm{~km} \times 40 \mathrm{~km}$ pixel size and GOME-2B measuring with $1920 \mathrm{~km}$ swath width and $40 \mathrm{~km} \times 80 \mathrm{~km}$ pixel size. 
The GOME-2 water vapour total column data are aimed mainly for climatological studies. In contrast to near-infrared and GPS radio-occultation measurements, the retrieval algorithm uses no external input of the state of the atmosphere. Thus GOME-2 data are fully independent of measurements from other instruments and/or modelling at a cost of possible larger uncertainties of the individual measurements.

The retrieval uses the differential optical absorption spectroscopy (DOAS) algorithm with a 614-683 nm fitting window to obtain slant columns of atmospheric water vapour, followed by a non-linearity absorption correction and finally by the air mass factor (AMF) conversion to generate vertical total columns. The air mass correction factor is determined using $\mathrm{O}_{2}$ absorption in the same fitting window. The detailed description of the algorithm and data can be found in the Algorithm Theoretical Basis Document (Valks et al., 2013a) and the Product User Manual (Valks et al., 2013b), both available at the O3M SAF website (http://o3msaf.fmi.fi), as well as in the recent paper by Grossi et al. (2015).

\section{Radiosonde and GPS data sources}

The Integrated Global Radiosonde Archive (IGRA) is a radiosonde data set maintained by the National Climatic Data Center (NCDC) (http://www.ncdc.noaa.gov/data-access/ weather-balloon/integrated-global-radiosonde-archive).

IGRA contains quality-assured observations from 1500 globally distributed stations with different periods of record from 1960s to present. For the period considered for this validation, the source of the data is the NCDC real-time Global Telecommunication System (GTS) data set. The quality assurance procedures are described in detail by Durre et al. (2006). As of 2003, $74 \%$ (35\%) of all soundings reached the $100 \mathrm{hPa}(10 \mathrm{hPa})$ level. An average sounding has 46 levels (with a vertical resolution of about $0.5 \mathrm{~km}$ ). The IGRA database contains soundings from several different radiosonde types with different processing and is, as a result, a rather inhomogeneous data set (Wang and Zhang, 2008). It is, however, widely used in climate studies and provides the longest available record of upper air temperatures and humidity. Independent uncertainty estimates for water vapour columns from radiosonde profiles have not, so far, been reported in the literature. However, comparisons with ground-based observations show an estimated precision of about 5\% (Van Malderen et al., 2014). (Wang and Zhang, 2008) report mean dry bias of $-1.19 \mathrm{~mm}(-6.8 \%)$ for capacitive polymer sondes and mean moist biases of $1.01 \mathrm{~mm}(3.4 \%)$ and $0.76 \mathrm{~mm}(5.4 \%)$ for carbon hygristor and Goldbeater's skin hygrometers, respectively.

The COSMIC/SuomiNet network is a ground-based GPS network designed for real-time remote sensing of atmospheric water vapour. The network provides integrated atmospheric water vapour columns and the total electron content from globally distributed GPS stations. Precipitable water es- timates are provided for each station at $30 \mathrm{~min}$ time resolution (Ware et al., 2000). We note that the GPS data were missing for the period 8 August 2009-7 February 2010.

\section{Data selection and co-locations}

In all comparisons, the GOME-2 measurements were screened for cloudy scenes. Two separate cloud indicators are used to flag cloudy pixels. The first cloud flag is triggered if the effective cloud fraction (the product of cloud top albedo and geometric cloud fraction) exceeds 0.6 , indicating a very high cloud top reflection. The second flag is set if the retrieved $\mathrm{O}_{2}$ slant column is below $80 \%$ of the maximum for the respective solar zenith angle. This requirement ensures that the main part of the $\mathrm{O}_{2}$ slant column used in the calculation of the air mass factor correction is visible. Both flags were used in the screening.

The measurements with solar zenith angle $>75^{\circ}$ were discarded to exclude low light conditions. Only forward-scan pixels were used for comparisons, since back-scan pixels are of a larger size and are currently not recommended for use. Of the forward-scan co-locations available, about $20 \%$ have solar zenith angle $>75^{\circ}, 20 \%$ have the first cloud flag set and $50 \%$ have the second cloud flag set. This leaves about $40 \%$ of the co-locations for the validation. GOME-2A observations are compared from January 2007 to July 2013 and GOME-2B observations from 13 December 2012 to July 2013. Data used in the comparisons are processed using the GOME Data Processor (GDP) version 4.7, which has been operational since July 2013.

For our analysis of the radio soundings, we selected the measurements where the stations are located within the GOME-2 ground pixel and the sounding times coincide within $3 \mathrm{~h}$ of the Metop overpass. We will henceforth refer to these conditions (located within the ground pixel, specified timing coincidence criteria) as co-locations. This means that the centres of GOME-2 pixels (nominally $40 \mathrm{~km} \times 80 \mathrm{~km}$ ) are within $50 \mathrm{~km}$ of the sonde launch sites in majority of cases. The water vapour columns were calculated by integrating the specific humidity measurements from the surface up to the altitude of the lapse-rate tropopause, which is specified in the IGRA profiles. Soundings without an identified tropopause were discarded. Only profiles with more than 20 altitude levels were used for the analysis. Screening for incomplete soundings removes about $18 \%$ of the co-locations. After the screening, the total number of co-locations with the radiosondes was about 480000 for GOME-2A and 44000 for GOME-2B.

Similarly, we use GPS measurements located within the GOME-2 ground pixels. Because of the better temporal resolution of the GPS measurements, only the observations with smallest available time difference to the Metop overpass were selected for each coincidence. Since the GPS retrievals are available all day at a frequency of $30 \mathrm{~min}$, only 

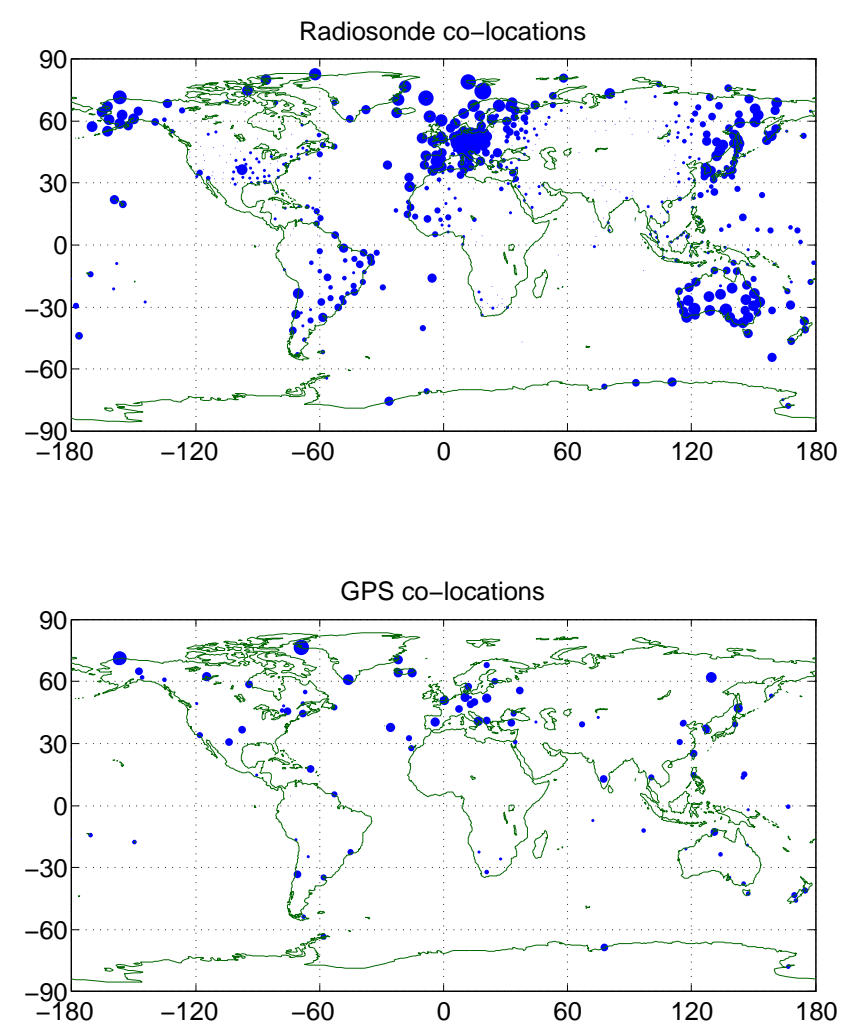

Figure 1. Locations of the GOME-2A co-locations with radiosondes (top) and GPS (bottom). Size of the markers is proportional to the number of co-located data.

co-locations where the time difference between the GOME2 overpass and the GPS retrieval was less than $15 \mathrm{~min}$ were used. Following a recommendation from the processing team, we have only used the GPS measurements that have a formal error of the precipitable water vapour (as specified in the data files) not exceeding $0.3 \mathrm{~mm}$. The requirement for the 15 min maximum time difference removes $3 \%$ of the colocations, and the screening for the formal error $0.3 \%$ of the co-locations. The total number of co-locations with the GPS was about 94000 for GOME-2A and 9000 for GOME-2B. All the radiosonde and GPS co-locations are shown in Fig. 1.

\section{Results and discussion}

\subsection{Overall agreement}

To illustrate the overall agreement between the data sets, we present the scatter plots of the GOME-2A and GOME-2B measurements vs. the co-located radiosonde and GPS measurements. For each range of ground-based water vapour column values, we computed the percentiles of the GOME-2 distributions. Figure 2 shows the median (solid thick line), 5th and 95th percentiles (thin solid lines), and 25th and 75th percentiles (dashed lines). The moderate values of GOME2 water vapour are in a very good agreement with both radiosonde and GPS data, while large water vapour abundances (above $50 \mathrm{~kg} \mathrm{~m}^{-2}$ ) are smaller in the GOME-2 data sets than in the co-located ground-based data. Large water vapour abundances are commonly associated with high cloud top heights and cloud top albedos and are less likely to include cloud-free scenes (not shown here). These factors are shown by (Antón et al., 2015) to be associated with dry biases.

The statistics of the overall comparison, calculated from all available screened co-locations, are shown in Table 1. We find good correlations of both the GOME-2A and GOME-2B with the radiosonde and GPS data, with correlation coefficients of 0.91 (radiosondes) and 0.94 (GPS). The GOME-2 data show a negative (dry) median difference against the radiosondes and a positive (wet) median difference against the GPS observations. The mean relative differences are fairly large due to the very high relative differences seen at low values (see also below).

As seen in the scatter plots (Fig. 2) the overall biases are largely independent of the water vapour abundances between $8-50 \mathrm{~kg} \mathrm{~m}^{-2}$. At the edges of the total column water vapour (TCWV) range, a dependency is observed. For larger TCWV, this dependency is likely related to non-linearity (saturation) correction used to compensate for GOME-2 instruments inability to spectrally resolve the finely structured $\mathrm{H}_{2} \mathrm{O}$ bands (Grossi et al., 2015). This is also observed in Fig. 3, which shows the median relative differences and the 5th, 25th, 75th and 95th percentiles as a function of the radiosonde and GPS observations. For water vapour values in the range of $8-50 \mathrm{~kg} \mathrm{~m}^{-2}$, the relative differences are small and within $\pm 5 \%$. At low values, below $8 \mathrm{~kg} \mathrm{~m}^{-2}$, the large positive bias in GOME-2 is clearly visible, especially against the GPS data.

Figure 4 shows the time series of the global monthly median difference (GOME-2 - radiosonde/GPS) with the 5th, 25th, 75th and 95th percentiles of the monthly distributions. The global median difference shows some seasonal variations with a magnitude of about $1 \mathrm{~kg} \mathrm{~m}^{-2}$. There is no visible drift in the mean differences during the comparison period; the estimated drifts are very small, less than $0.005 \mathrm{~kg} \mathrm{~m}^{-2} \mathrm{dec}^{-1}$ (less than $0.03 \% \mathrm{dec}^{-1}$ ) and are not statistically significant. No significant difference can be seen in the behaviour of GOME-2A and B. (Grossi et al., 2015) reported a small positive overall bias (less than $1 \%$ ) for GOME-2B over GOME-2A, with largest biases (2-3\%) in equatorial area.

\subsection{Classification of the biases}

\subsubsection{Scan angle dependency}

The validation studies of the previous GOME-2 processor versions have shown the strong dependence of the GOME-2 water vapour on the scan angle (e.g. Noël et al., 2008). This dependence results in a bias in total column water vapour be- 

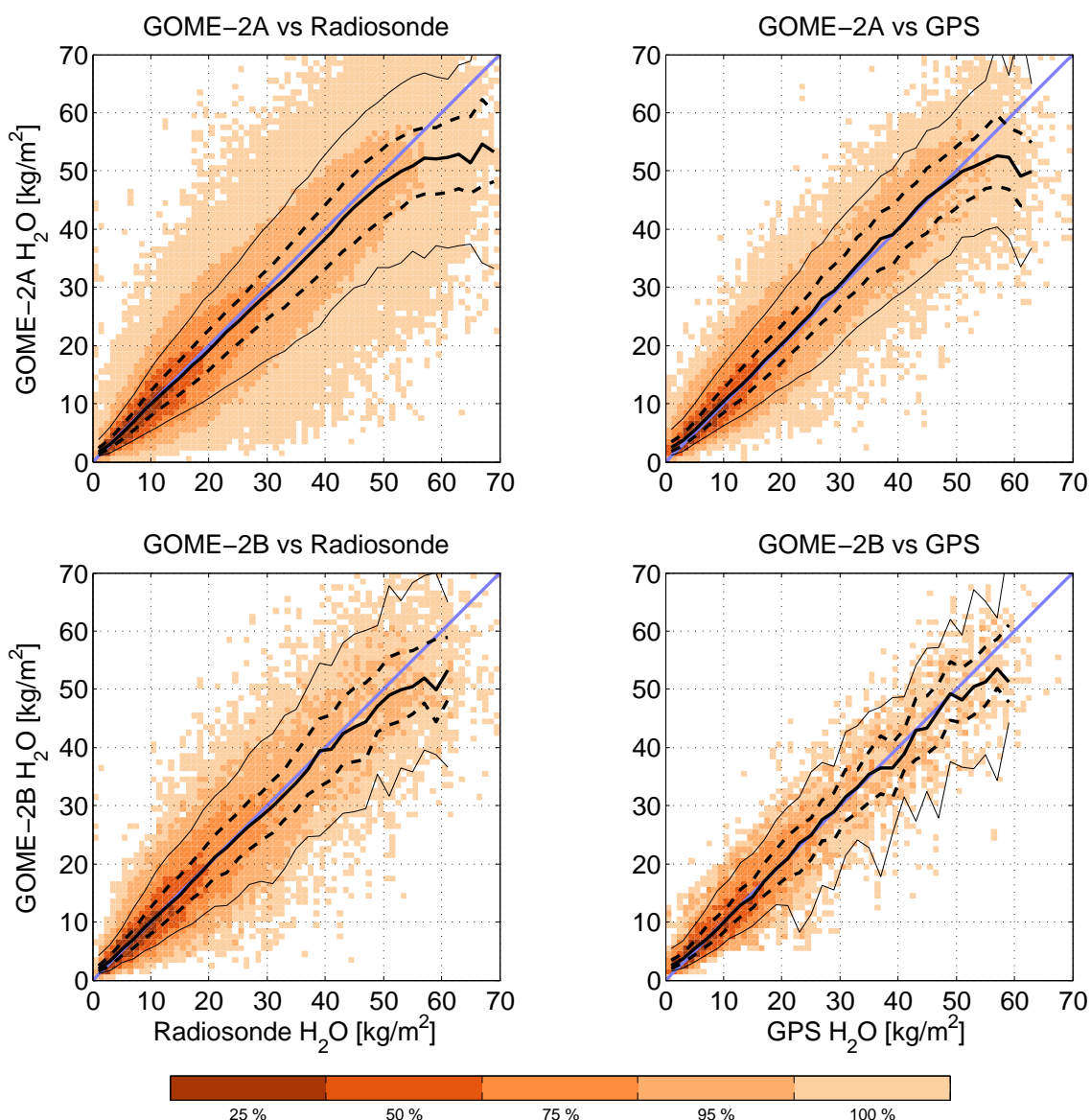

Figure 2. Scatter plot of GOME-2A (top) and GOME-2B (bottom) total water vapour columns against the IGRA integrated total water vapour columns (left) and COSMIC/SuomiNet GPS water vapour (right). Colour represents the fraction of hits, solid line is the median of the GOME-2 water vapour column in $2 \mathrm{~kg} \mathrm{~m}^{-2}$ bin, dashed lines 25 and $75 \%$ percentiles and thin solid lines 5 and $95 \%$ percentiles. Solid blue line is $x=y$ line.

Table 1. Statistics of comparisons between GOME-2A and B with radiosondes and GPS observations.

\begin{tabular}{lrrrrrr}
\hline & $\begin{array}{r}\text { Correlation } \\
\text { coefficient }\end{array}$ & $\begin{array}{r}\text { Mean } \\
\text { difference }\end{array}$ & $\begin{array}{r}\text { Mean relative } \\
\text { difference }\end{array}$ & $\begin{array}{r}\text { Standard } \\
\text { deviation }\end{array}$ & $\begin{array}{r}\text { Median } \\
\text { difference }\end{array}$ & $\begin{array}{r}\text { Median relative } \\
\text { difference }\end{array}$ \\
\hline GOME-2A - sonde & 0.910 & $-0.44 \mathrm{~kg} \mathrm{~m}^{-2}$ & $0.38 \%$ & $5.27 \mathrm{~kg} \mathrm{~m}^{-2}$ & $-0.32 \mathrm{~kg} \mathrm{~m}^{-2}$ & $-2.7 \%$ \\
GOME-2A - GPS & 0.936 & $0.63 \mathrm{~kg} \mathrm{~m}^{-2}$ & $14.9 \%$ & $4.48 \mathrm{~kg} \mathrm{~m}^{-2}$ & $0.50 \mathrm{~kg} \mathrm{~m}^{-2}$ & $4.9 \%$ \\
GOME-2B - sonde & 0.909 & $0.03 \mathrm{~kg} \mathrm{~m}^{-2}$ & $11.8 \%$ & $5.53 \mathrm{~kg} \mathrm{~m}^{-2}$ & $-0.03 \mathrm{~kg} \mathrm{~m}^{-2}$ & $-0.3 \%$ \\
GOME-2B - GPS & 0.941 & $0.25 \mathrm{~kg} \mathrm{~m}^{-2}$ & $16.8 \%$ & $4.51 \mathrm{~kg} \mathrm{~m}^{-2}$ & $0.33 \mathrm{~kg} \mathrm{~m}^{-2}$ & $3.2 \%$ \\
\hline
\end{tabular}

tween west and east parts of the GOME-2 swath and the centre of the swath. In the GDP v.4.7, the scan angle dependency of the measurements has been removed to a large extent by a semi-empirical correction (Grossi et al., 2015). To investigate the quality of the applied scan-angle correction, we show the median relative difference of the GOME-2A and $B$ observations against the radiosonde and GPS observations for different line-of-sight zenith angles, as well as the 5th, 25th, 75th and 95th percentiles of the distribution (Fig. 5).
The negative zenith angles in Fig. 5 refer to the eastern half of the swath and positive ones to the western half. The results show that the scan-angle dependence of the GOME2 data is small. However, the western edge of the GOME-2 swath shows about $5 \%$ higher water vapour column than the eastern one in comparisons with the radiosonde observations. Against the GPS observations, both edges of the swath show a wet bias of about $10 \%$ compared to the centre of the swath. Compared to the validation of the previous algorithm version presented in (Grossi et al., 2013), this is a clear improvement. 

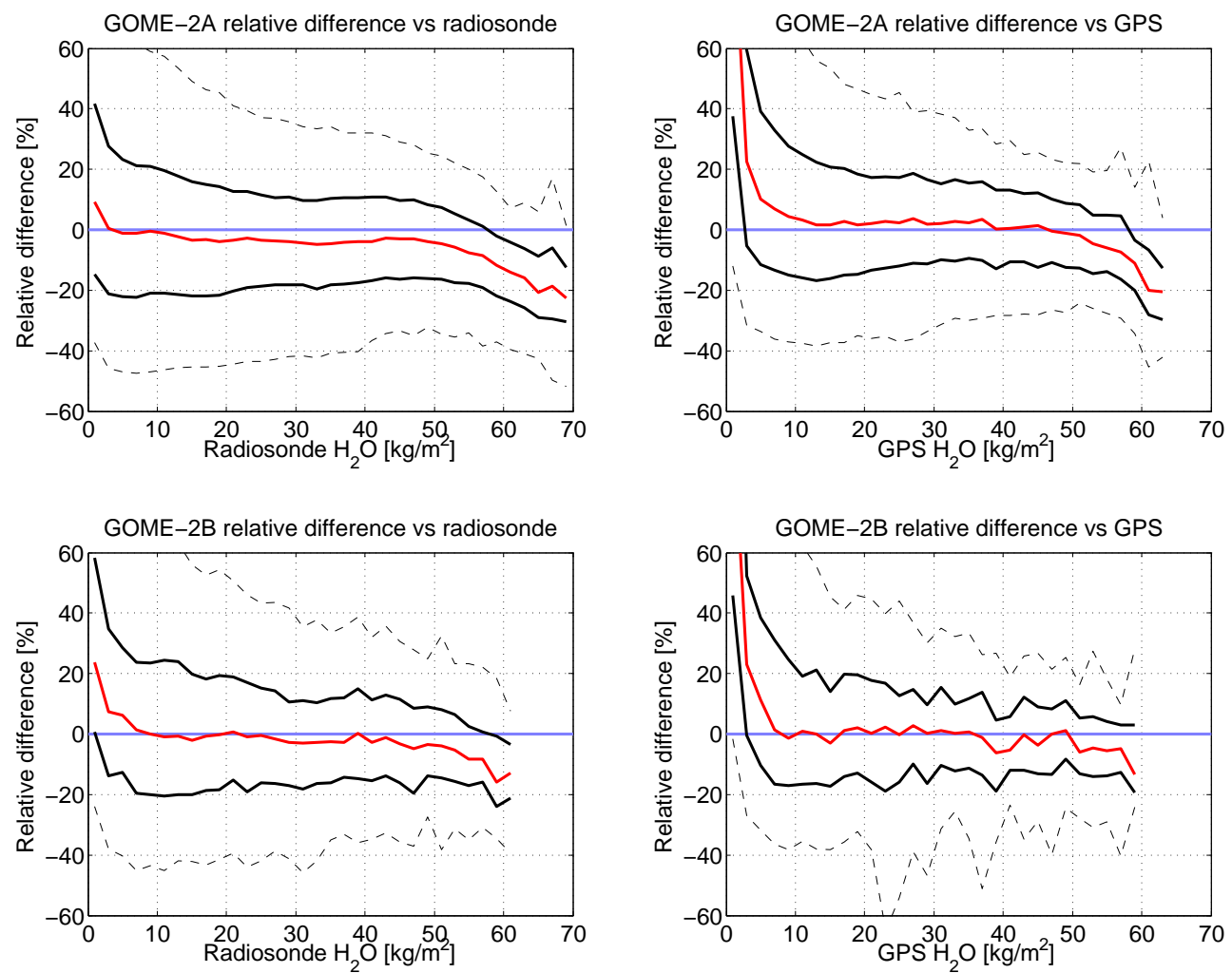

Figure 3. Median relative differences (red solid line), 25 and $75 \%$ percentiles (black solid lines) and 5 and $95 \%$ percentiles (dashed lines) for GOME-2A (top) and GOME-2B (bottom) against radiosonde (left) and GPS (right).
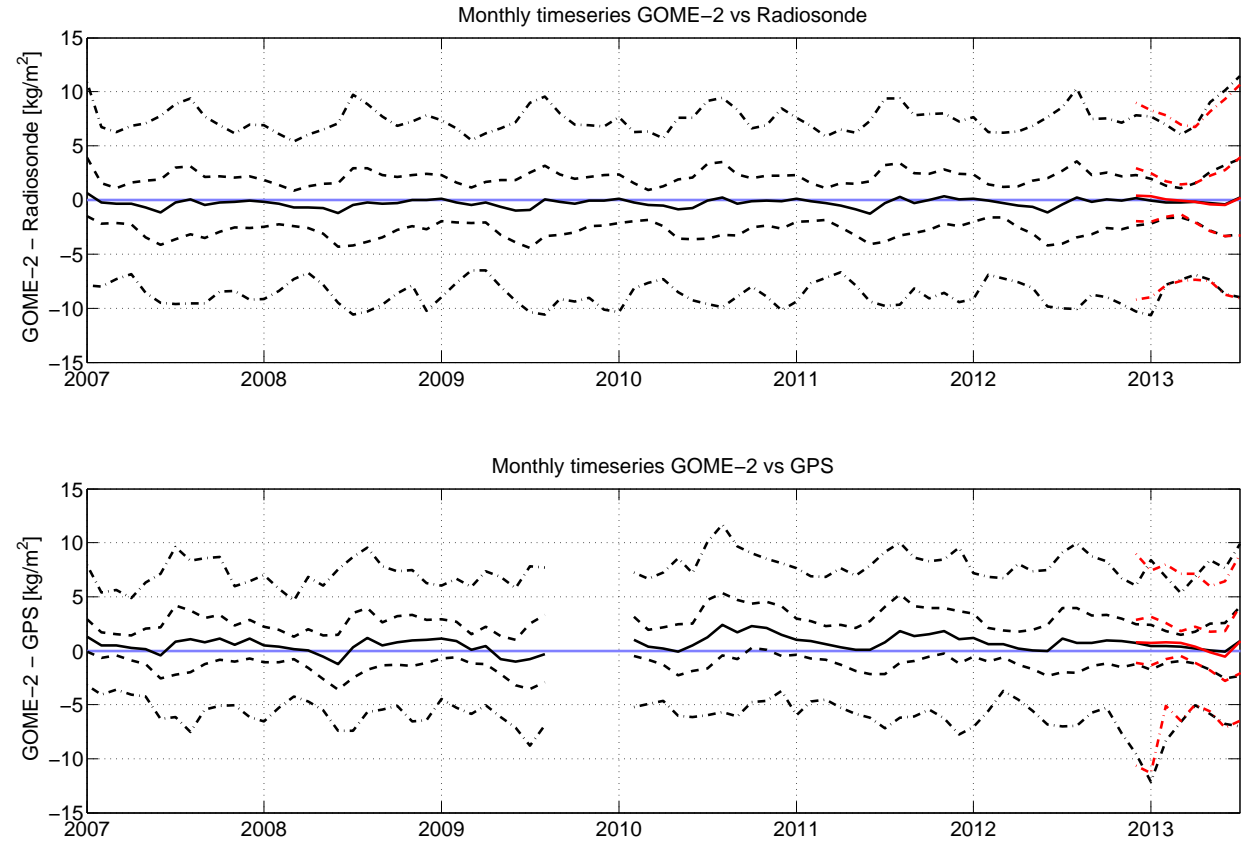

Figure 4. Time series of global monthly median differences (solid line), 25 and $75 \%$ percentiles (dashed lines) and 5 and $95 \%$ percentiles (dash-dot lines) for GOME-2A (black) and GOME-2B (red) against radiosonde (top) and GPS (bottom). 

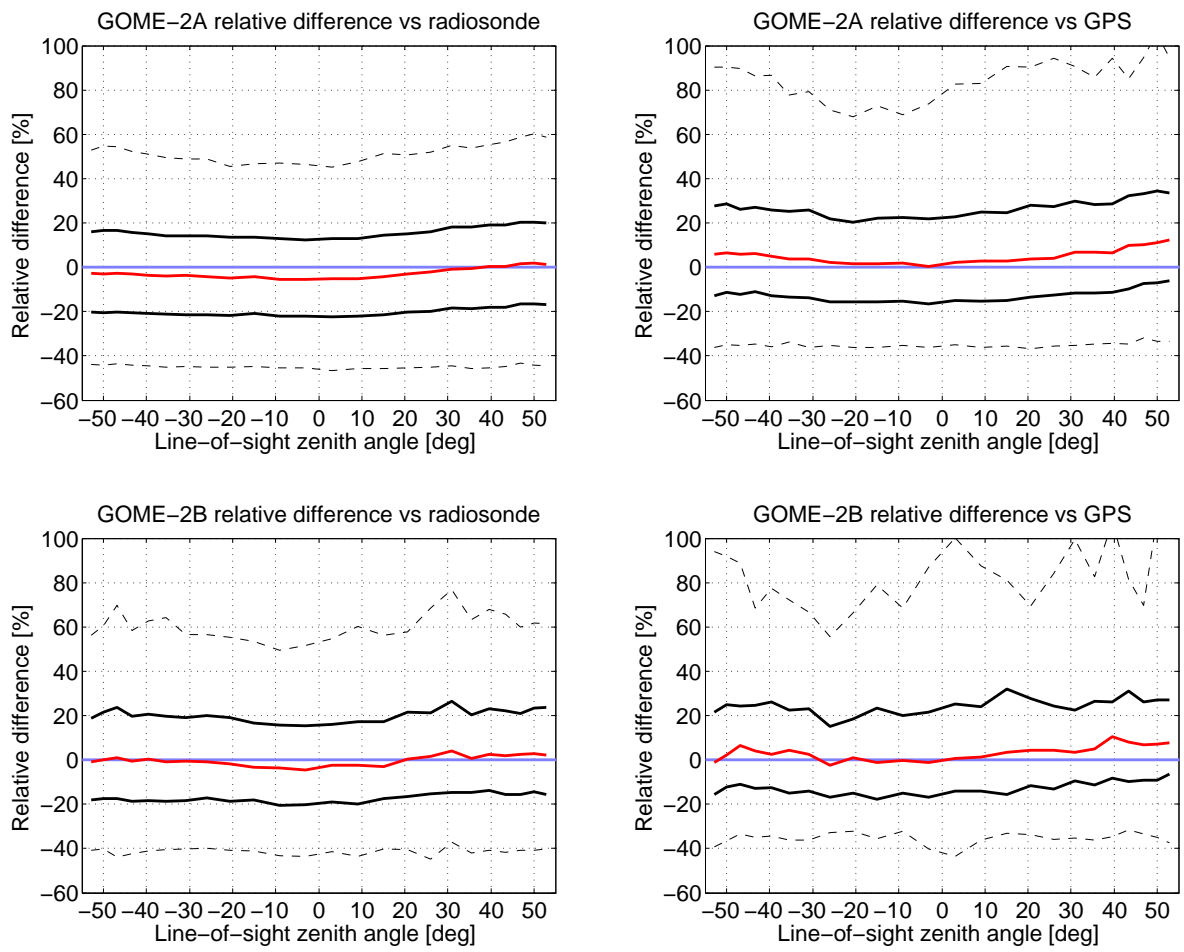

Figure 5. Median relative differences (red solid line), 25 and $75 \%$ percentiles (black solid lines) and 5 and $95 \%$ percentiles (dashed lines) for GOME-2A (top) and GOME-2B (bottom) against radiosonde (left) and GPS (right) as a function of line-of-sight zenith angle at the centre of the GOME-2 pixel. Negative angles correspond to the eastern edge of the swath and positive to the western. Only observations from full-swath $(1920 \mathrm{~km})$ scans are used in analysis.
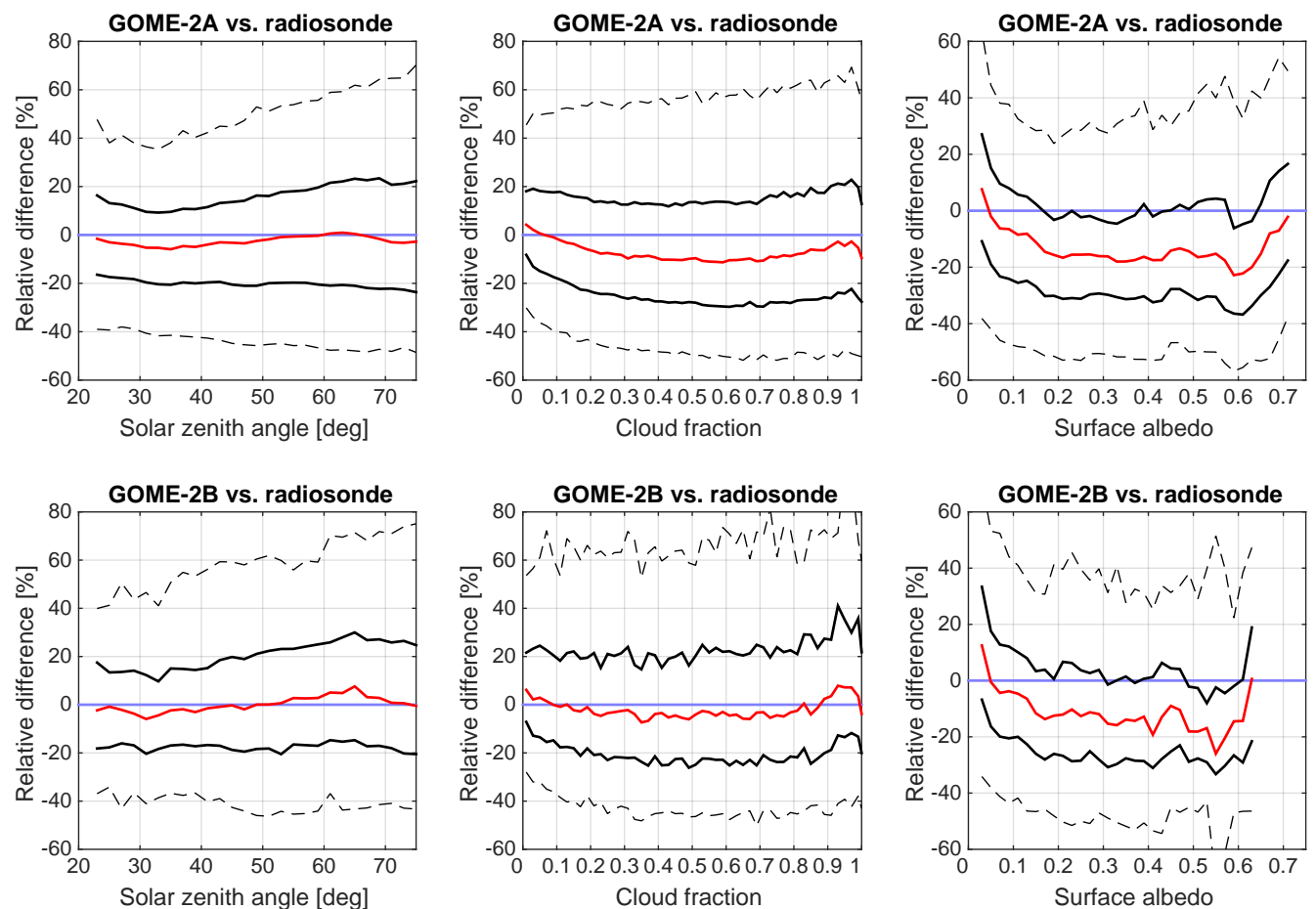

Figure 6. Median relative differences (red solid line), 25 and $75 \%$ percentiles (black solid lines) and 5 and $95 \%$ percentiles (dashed lines) for GOME-2A (top) and GOME-2B (bottom) against radiosonde as a function of solar zenith angle (left), geometric cloud fraction (centre) and surface albedo (right). 
Table 2. Statistics of comparisons between GOME-2A with radiosondes over different surface types.

\begin{tabular}{|c|c|c|c|c|c|c|c|}
\hline & $\begin{array}{l}\text { Correlation } \\
\text { coefficient }\end{array}$ & $\begin{array}{r}\text { Mean } \\
\text { difference }\end{array}$ & $\begin{array}{r}\text { Mean relative } \\
\text { difference }\end{array}$ & $\begin{array}{l}\text { Standard } \\
\text { deviation }\end{array}$ & $\begin{array}{r}\text { Median } \\
\text { difference }\end{array}$ & $\begin{array}{r}\text { Median relative } \\
\text { difference }\end{array}$ & $N$ \\
\hline Land & 0.901 & $-0.98 \mathrm{~kg} \mathrm{~m}^{-2}$ & $-2.3 \%$ & $5.10 \mathrm{~kg} \mathrm{~m}^{-2}$ & $-0.60 \mathrm{~kg} \mathrm{~m}^{-2}$ & $-4.3 \%$ & 318067 \\
\hline Sea & 0.906 & $1.45 \mathrm{~kg} \mathrm{~m}^{-2}$ & $12.0 \%$ & $6.15 \mathrm{~kg} \mathrm{~m}^{-2}$ & $1.37 \mathrm{~kg} \mathrm{~m}^{-2}$ & $9.2 \%$ & 103371 \\
\hline Ice & 0.855 & $-1.21 \mathrm{~kg} \mathrm{~m}^{-2}$ & $-15.0 \%$ & $2.28 \mathrm{~kg} \mathrm{~m}^{-2}$ & $-0.93 \mathrm{~kg} \mathrm{~m}^{-2}$ & $-19.2 \%$ & 34086 \\
\hline
\end{tabular}
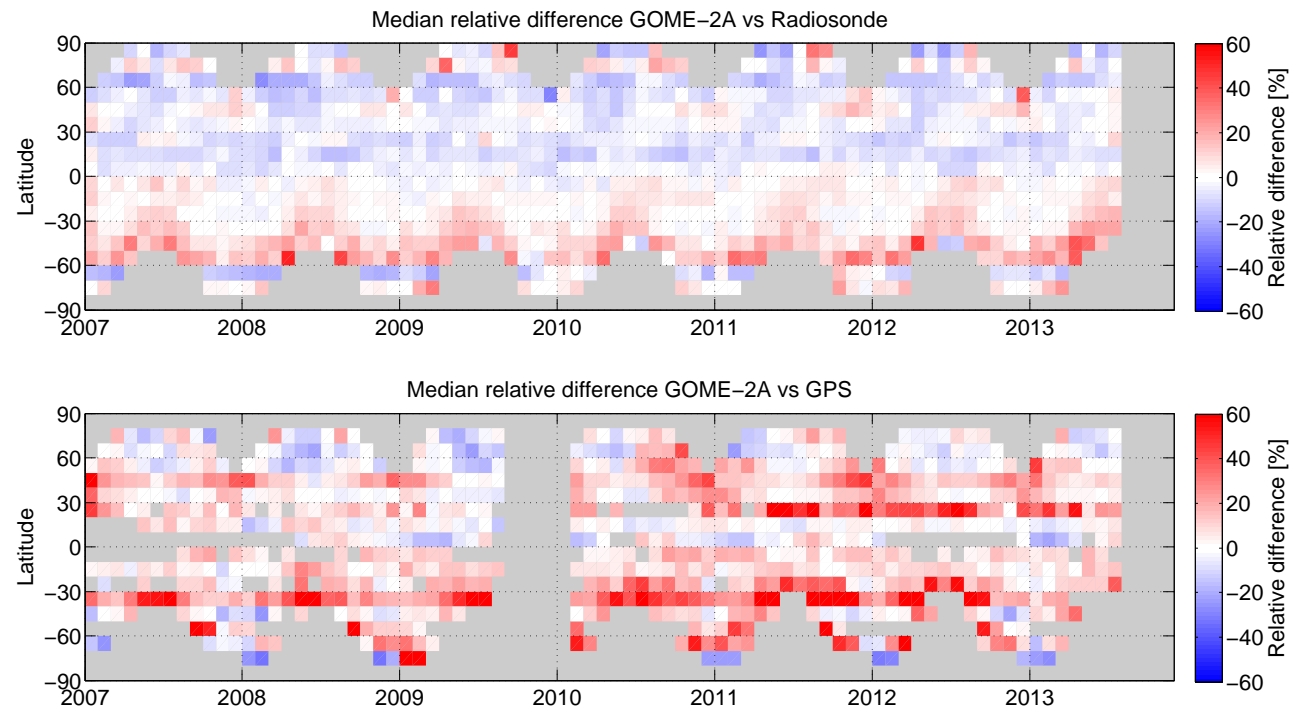

Figure 7. Monthly median relative difference (\%) as a function of time and latitude, GOME-2A vs. radiosonde (top) and GPS (bottom). Each coloured box shows the median relative difference for one month in $10^{\circ}$ latitude zone. Month-latitude bins with fewer than 10 co-locations are not shown.

\subsubsection{Solar zenith angle, cloud fraction, and surface albedo}

As discussed by (Grossi et al., 2015) the quality of the GOME-2 water vapour data may also depend on the solar zenith angle, the cloud fraction and the surface albedo, due to approximations in the retrieval algorithm. To investigate the influence of these factors, the relative differences between the GOME-2A and GOME-2B data and the co-located radiosonde observations are presented as functions of solar zenith angle, geometric cloud fraction and surface albedo (Fig. 6).

The median deviations from the radiosonde data depend weakly on the solar zenith angle (Fig. 6 left panels): they are $5-10 \%$ higher for larger solar zenith angles. The scatter of the relative difference distribution increases with increasing solar zenith angle. This is probably due to a larger fraction of data with smaller water vapour abundances being observed at large solar zenith angles. (Antón et al., 2015) observed similar behaviour while also reporting positive bias for cloud-free cases at solar zenith angles above $50^{\circ}$. Large positive differences observed at low water vapour amounts (Fig. 3) are related to clouds at high solar zenith angles. Most of the lowest values, where bias is highest, are observed at solar zenith angles higher than $60^{\circ}(90 \%$ of the cases) with cloud fraction 1 ( $66 \%$ of the cases).

As described earlier, for our analysis a cloud screening was applied. Despite this, a difference of similar magnitude can be seen for observations with very small or large geometric cloud fraction, compared to observations in moderately cloudy situations (Fig. 6, centre). The range of these variations is about $15 \%$. This is similar to behaviour observed by (Antón et al., 2015). (Grossi et al., 2015) also reported residual cloud effects in comparisons with ECMWF ERA-Interim and combined SSM/I-MERIS data sets.

Right panels of Fig. 6 show the impact of the surface albedo on the differences with respect to the radiosonde data. For darkest surfaces (albedo $<0.05$ ), positive (wet) bias is observed. Negative (dry) bias of $10-20 \%$ is observed for larger albedos $(>0.15)$. Table 2 shows the statistics of the comparisons of the GOME-2A observations with the radiosondes over different surface types (land, sea or snow/ice). The biases obtained here agree with the ones observed in Fig. 6 (right panels), considering the typical albedo values for each surface type. Small negative bias is observed over land (median albedo 0.06). Sea pixels (median albedo 

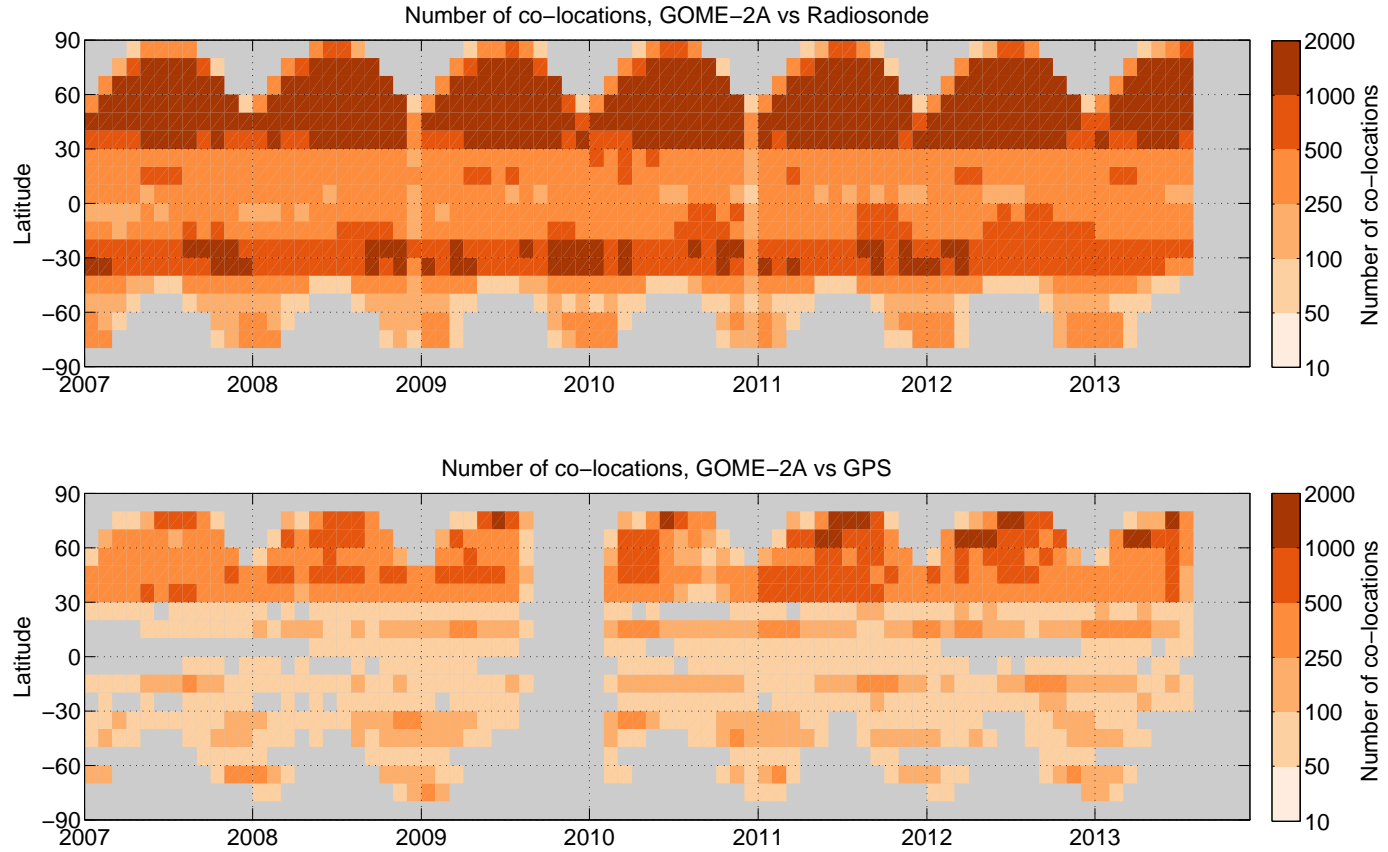

Figure 8. Number of co-locations per month and $10^{\circ}$ latitude zone, for GOME-2A vs. radiosonde (top) and GPS (bottom).
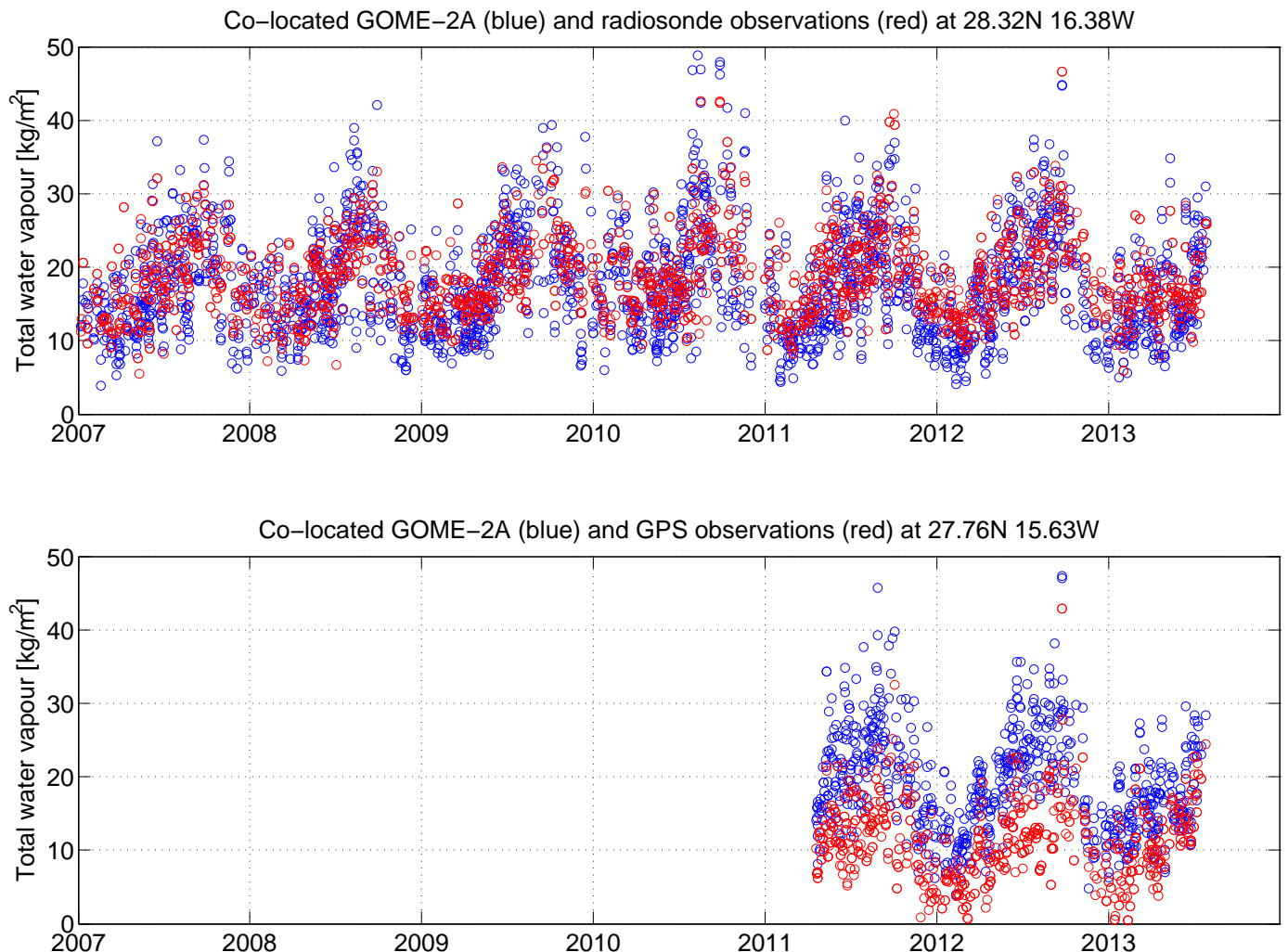

Figure 9. Top: time series of co-located observations for GOME-2A (blue) and radiosonde (red) at 28.32 ${ }^{\circ} \mathrm{N}, 16.38^{\circ} \mathrm{W}$. Bottom: GOME-2A (blue) and GPS (red) at $27.76^{\circ} \mathrm{N}, 15.63^{\circ} \mathrm{W}$. Since the GPS network is sparser than the radiosonde network (see Fig. 1), large biases or poor temporal representativeness at individual stations can affect the biases at certain latitude bands to a larger degree than in the case of comparisons with radiosoundings (see Fig. 7). 
0.03) show a positive bias, while pixels classified as ice or snow (median albedo 0.30) show large negative biases. In the GOME-2 retrievals, the surface albedo map derived from GOME and SCIAMACHY observations (Koelemeijer et al., 2003; Grzegorski, 2009) is the only external information; it has rather large uncertainties, especially over oceans where the information about the albedo is limited. Future developments of the GOME-2 algorithm and the surface albedo databases might help improve the albedo correction (Grossi et al., 2015).

\subsubsection{Season and latitude}

The illustration of the seasonal and latitudinal dependences of the biases with respect to the ground-based data sets is presented in Fig. 7. Here, we show monthly zonal medians of the relative differences between the GOME-2 and the ground-based measurements in $10^{\circ}$ latitude zones. When compared with sondes, GOME-2A generally has a wet bias in the Southern Hemisphere and a dry bias in the Northern Hemisphere. This is likely due to the distribution of the colocations and the difference in bias between continental and ocean areas, as observed by (Grossi et al., 2015). Seasonal variations in the differences can be seen at mid-latitudes, especially in the Southern Hemisphere. These seasonal variations at mid-latitudes are in a broad agreement with the general dependence of the GOME-2 biases shown in Fig. 3: a negative/smaller bias in wet seasons (summer) and a positive/larger bias in dry seasons (winter). Comparisons with the GPS show a wet bias in most areas with a stronger bias in the Southern Hemisphere.

We note here that the seasonal-latitudinal structures presented in Fig. 7 need to be carefully taken into consideration because of the following reasons: firstly, the number on colocated measurements in the latitude-month bins are quite different (illustrated in Fig. 8). This means that the bias estimates for some bins may not be statistically significant. Secondly, as discussed by (Grossi et al., 2015), the GOME-2 biases have a pronounced zonal structure (which is associated with e.g. the surface albedo, as discussed above), while the ground-based stations are distributed highly non-uniformly in longitude, especially the GPS stations. Thirdly, some of the larger differences in the comparison against the GPS observations are a result of large differences observed at a small number of stations. Let us consider the latitude zone 20 $30^{\circ} \mathrm{N}$, for example. As shown in Fig. 7, a large positive bias against the GPS is observed starting from May 2011, while such a bias is not observed against the radiosondes. A large fraction of the data in this latitude zone is from the stations at $27-28^{\circ} \mathrm{N}, 15-17^{\circ} \mathrm{W}$ (both radiosonde and GPS stations are available). Figure 9 shows an example time series of the co-located GOME-2A and radiosonde/GPS observations in this region, located less than $100 \mathrm{~km}$ from each other. While the radiosonde observations generally match the GOME-2A very closely, the GPS observations are much lower. This ex- plains the strange appearance of a strong bias in comparisons with the GPS at $20-30^{\circ} \mathrm{N}$ after May 2011. Excluding these, the overall distributions shown in Fig. 7 are in a broad agreement with the magnitude and structure of the biases discussed in Sect. 5.1.

\section{Conclusions}

We have performed the global validation of O3M SAF total column water vapour from GOME-2A (January 2007 to August 2013) and GOME-2B (December 2012 to August 2013) using radiosonde data from the IGRA archive and the GPS data from the COSMIC/SuomiNet network. Overall, the GOME-2 data agree well with both data sets: correlation coefficients are higher than 0.9 for all comparisons. Small negative (dry) median differences (GOME-2A: $-2.7 \%$, GOME2B: $-0.3 \%)$ are observed against radiosonde, while positive (wet) median difference (GOME-2A: 4.9\%, GOME2B: $3.2 \%$ ) is obtained against GPS. Moderate values of the GOME-2 water vapour of $8-50 \mathrm{~kg} \mathrm{~m}^{-2}$ are in a very good agreement with both radiosonde and GPS data (the relative difference is within $\pm 5 \%$ ), while high values show a pronounced dry bias and small values exhibit a strong wet bias, in all comparisons. A strong dependence of GOME-2 biases on the surface albedo is found, from a strong positive (wet) bias for very dark surfaces (albedo $<0.05$ ) to a negative bias of up to $20 \%$ for observations with albedo above 0.15 . The dependence of the GOME-2 biases on solar zenith angles and cloudiness is smaller; the relative differences with respect to the radiosonde data vary within $15 \%$. GOME-2A generally shows a good ability to represent the seasonal variations of water vapour. No trend in the median difference with the radiosonde data is apparent during the validation period. Notably the behaviour of the GOME-2A and B was very similar in all comparisons. This opens up the opportunity for combined use of the GOME-2A and GOME-2B data.

Acknowledgements. The authors would like to thank the Integrated Global Radiosonde Archive (IGRA) for the radiosonde data and the COSMIC/SuomiNet project for the GPS data.

The work of FMI team was funded by the EUMETSAT Satellite Application Facility on Ozone and Atmospheric Chemistry Monitoring (O3M SAF) and Finnish Academy projects CLASP (\#265005), ASTREX and INQUIRE.

Edited by: P. Stammes 


\section{References}

Anthes, R. A., Ector, D., Hunt, D. C., Kuo, Y-H., Rocken, C., Schreiner, W. S., Sokolovskiy, S. V., Syndergaard, S., Wee, TK., Zeng, Z., Bernhardt, P. A., Dymond, K. F., Chen, Y., Liu, H., Manning, K., Randel, W. J., Trenberth, K. E., Cucurull, L., Healy, S. B., Ho, S.-P., McCormick, C., Meehan, T. K., Thompson, D. C., and Yen, N. L.: The COSMIC/FORMOSAT-3 Mission: Early Results, B. Am. Meteorol. Soc., 89, 313-333, 2008.

Antón, M., Loyola, D., Román, R., and Vömel, H.: Validation of GOME-2/MetOp-A total water vapour column using reference radiosonde data from the GRUAN network, Atmos. Meas. Tech., 8, 1135-1145, doi:10.5194/amt-8-1135-2015, 2015.

Bennartz, R. and Fischer, J.: Retrieval of columnar water vapour over land from backscattered solar radiation using the Medium Resolution Imaging Spectrometer, Remote Sens. Environ., 78, 274-283, 2001.

Chaboureau, J.-P., Chédin, A., and Scott, N. A.: Remote sensing of the vertical distribution of atmospheric water vapor from the TOVS observations: method and validation, J. Geophys. Res.Atmos., 103, 8743-8752, 1998.

du Piesanie, A., Piters, A. J. M., Aben, I., Schrijver, H., Wang, P., and Noël, S.: Validation of two independent retrievals of SCIAMACHY water vapour columns using radiosonde data, Atmos. Meas. Tech., 6, 2925-2940, doi:10.5194/amt-6-2925-2013, 2013.

Durre, I., Vose, R. S., and Wuertz, D. B.: Overview of the integrated global radiosonde archive, J. Climate, 19, 53-68, 2006.

Gao, B. C. and Kaufman, Y. J.: Water vapor retrievals using Moderate Resolution Imaging Spectroradiometer (MODIS) near-infrared channels, J. Geophys. Res.-Atmos., 108, 4389, doi:10.1029/2002JD003023, 2003.

Grossi, M., Kalakoski, N., Valks, P.: Interim verification report of GOME-2 GDP $4.7 \mathrm{H}_{2} \mathrm{O}$ column data for MetOp-B Operational Readiness Review, available at: http://o3msaf.fmi.fi/ docs/vr/Validation_Report_OTO_H2O_May_2013.pdf (last access: 1 April 2016), 27 May 2013.

Grossi, M., Valks, P., Loyola, D., Aberle, B., Slijkhuis, S., Wagner, T., Beirle, S., and Lang, R.: Total column water vapour measurements from GOME-2 MetOp-A and MetOp-B, Atmos. Meas. Tech., 8, 1111-1133, doi:10.5194/amt-8-1111-2015, 2015.

Grzegorski, M.: Cloud retrieval from UV/VIS satellite instruments (SCIAMACHY and GOME), $\mathrm{PhD}$ thesis, University of Heidelberg, 1-215, 2009.

Kiehl, J. T. and Trenberth, K. E.: Earth's annual global mean energy budget, B. Am. Meteorol. Soc., 78, 197-208, 1997.

King, M. D., Kaufman, Y. J., Menzel, W., and Tanre, D.: Remote sensing of cloud, aerosol, and water vapor properties from the Moderate Resolution Imaging Spectrometer (MODIS), IEEE T. Geosci. Remote, 30, 2-27, 1992.

Koelemeijer, R. B. A., Haan, J. F. D., and Stammes, P.: A database of spectral surface reflectivity in the range 335-772 nm derived from 5.5 years of GOME observations, J. Geophys. Res., 108, 4070, doi:10.1029/2002JD002429, 2003.

Li, J., Wolf, W. W., Menzel, W. P., Zhang, W., Huang, H. L., and Achtor, T. H.: Global soundings of the atmosphere from ATOVS measurements: the algorithm and validation, J. Appl. Meteorol., 39, 1248-1268, 2000.
Mieruch, S., Schröder, M., Noël, S., and Schulz, J.: Comparison of monthly means of global total column water vapor retrieved from independent satellite observations, J. Geophys. Res.-Atmos., 115, D23310, doi:10.1029/2010JD013946, 2010.

Noël, S., Buchwitz, M., Bovensmann, H., Hoogen, R., and Burrows, J. P.: Atmospheric water vapor amounts retrieved from GOME satellite data, Geophys. Res. Lett., 26, 1841-1844, 1999.

Noël, S., Buchwitz, M., Bovensmann, H., and Burrows, J. P.: Retrieval of total water vapour column amounts from GOME/ERS2 data, Adv. Space Res., 29, 1697-1702, 2002.

Noël, S., Buchwitz, M., and Burrows, J. P.: First retrieval of global water vapour column amounts from SCIAMACHY measurements, Atmos. Chem. Phys., 4, 111-125, doi:10.5194/acp-4-1112004, 2004.

Noël, S., Buchwitz, M., Bovensmann, H., and Burrows, J. P.: Validation of SCIAMACHY AMC-DOAS water vapour columns, Atmos. Chem. Phys., 5, 1835-1841, doi:10.5194/acp-5-18352005, 2005.

Noël, S., Mieruch, S., Bovensmann, H., and Burrows, J. P.: Preliminary results of GOME-2 water vapour retrievals and first applications in polar regions, Atmos. Chem. Phys., 8, 1519-1529, doi:10.5194/acp-8-1519-2008, 2008.

Schlüssel, P. and Emery, W. J.: Atmospheric water vapour over oceans from SSM/I measurements, Int. J. Remote Sens., 11, 753766, 1990.

Susskind, J., Barnet, C. D., and Blaisdell, J. M.: Retrieval of atmospheric and surface parameters from AIRS/AMSU/HSB data in the presence of clouds, IEEE T. Geosci. Remote, 41, 390-409, 2003.

Valks, P., Loyola, D., Hao, N., Hedelt, P., Slijkhuis, S., and Grossi, M.: Algorithm Theoretical Basis Document for GOME-2 Total Column Products of Ozone, Tropospheric Ozone, $\mathrm{NO}_{2}$, Tropospheric $\mathrm{NO}_{2}, \mathrm{BrO}, \mathrm{SO}_{2}$, $\mathrm{H}_{2} \mathrm{O}, \mathrm{HCHO}, \mathrm{OClO}$ and Cloud Properties, available at: http://o3msaf.fmi.fi/docs/atbd/Algorithm_Theoretical_Basis_ Document_NTO_OTO_May_2013.pdf (last access: 1 April 2016), 21 May 2013a.

Valks, P., Loyola, D., Zimmer, W., Kiemle, S., Hao, N., Hedelt, P., Grossi, M., Pedergnana, M., Emmadi, S., Butenko, L., and Livschitz, Y.: Product User Manual for GOME Total Columns of Ozone, $\mathrm{NO}_{2}$, tropospheric $\mathrm{NO}_{2}, \mathrm{BrO}, \mathrm{SO}_{2}, \mathrm{H}_{2} \mathrm{O}, \mathrm{HCHO}, \mathrm{OClO}$, and Cloud Properties, available at: http://o3msaf.fmi.fi/docs/ pum/Product_User_Manual_NTO_OTO_Jun_2013.pdf (last access: 1 April 2016), 21 May 2013b.

Van Malderen, R., Brenot, H., Pottiaux, E., Beirle, S., Hermans, C., De Mazière, M., Wagner, T., De Backer, H., and Bruyninx, C.: A multi-site intercomparison of integrated water vapour observations for climate change analysis, Atmos. Meas. Tech., 7, 2487-2512, doi:10.5194/amt-7-2487-2014, 2014.

Wagner, T., Heland, J., Zöger, M., and Platt, U.: A fast $\mathrm{H}_{2} \mathrm{O}$ total column density product from GOME - Validation with insitu aircraft measurements, Atmos. Chem. Phys., 3, 651-663, doi:10.5194/acp-3-651-2003, 2003.

Wagner, T., Beirle, S., Grzegorski, M., Sanghavi, S., and Platt, U.: El Niño induced anomalies in global data sets of total column precipitable water and cloud cover derived from GOME on ERS-2, J. Geophys. Res.-Atmos., 110, D15104, doi:10.1029/2005JD005972, 2005. 
Wagner, T., Beirle, S., Grzegorski, M., and Platt, U.: Global trends (1996-2003) of total column precipitable water observed by Global Ozone Monitoring Experiment (GOME) on ERS-2 and their relation to near-surface temperature, J. Geophys. Res.Atmos., 111, D12102, doi:10.1029/2005JD006523, 2006.

Wang, J. and Zhang, L.: Systematic errors in global radiosonde precipitable water data from comparisons with ground-based GPS measurements, J. Climate, 21, 2218-2238, 2008.
Ware, R. H., Fulker, D. W., Stein, S. A., Anderson, D. N., Avery, S. K., Clark, R. D., Droegemeier, K. K., Kuettner, J. P., Minster, J. B., and Sorooshian, S.: Suominet: a real-time national GPS network for Atmospheric Research and education, B. Am. Meteorol. Soc., 81, 677-694, 2000. 